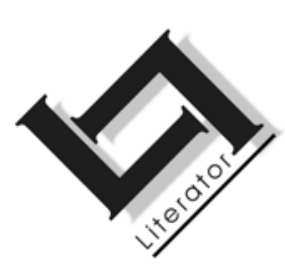

\title{
English South African children's literature and the environment
}

\author{
E.R. Jenkins \\ Professor Extraordinarius \\ Department of English Studies \\ University of South Africa \\ PRETORIA \\ E-mail: ejenkins@mweb.co.za
}

\begin{abstract}
English South African children's literature and the environment

Historical studies of nature conservation and literary criticism of fiction concerned with the natural environment provide some pointers for the study of South African children's literature in English. This kind of literature, in turn, has a contribution to make to studies of South African social history and literature. There are English-language stories, poems and picture books for children which reflect human interaction with nature in South Africa since early in the nineteenth century: from hunting, through domestication of the wilds, the development of scientific agriculture, and the changing roles of nature reserves, to modern ecological concern for the entire environment. Until late in the twentieth century the literature usually endorsed the assumption held by whites that they had exclusive ownership of the land and wildlife. In recent years English-language children's writers and translators of indigenous folktales for children have begun to explore traditional beliefs about and practices in conservation.
\end{abstract}

\section{Opsomming}

\section{Engelse Suid-Afrikaanse kinderliteratuur en die omgewing}

Historiese ondersoek van natuurbewaring en die literêre kritiek van fiksie oor die natuurlike omgewing bide ons 'n paar riglyne vir die bestudering van Suid-Afrikaanse kinderliteratuur in Engels. Hierdie soort literatuur kan op sy beurt weer 'n bydrae maak tot die bestudering van die Suid-Afrikaanse sosiale geskiedenis en letterkunde. Engelstalige verhale, gedigte en prenteboeke vir kinders is beskikbaar wat die mens se interaksie met die natuur sedert vroeg in die negentiende eeu weerspieël: van jag, die makmaak van die 
wildernis, die ontwikkeling van wetenskaplike landbou, die veranderende rolle van natuurreservate tot by die hedendaagse besorgdheid oor die hele ekologie. Tot laat in die twintigste eeu het hierdie tipe tekste gewoonlik blankes se aanname onderskryf dat hulle die alleenreg op die land en sy wildlewe het. Redelik onlangs het skrywers van kinderboeke in engels en die vertalers van inheemse volksverhale vir kinders begin om tradisionele oorlewerings oor bewaring en bewaringpraktyke te ondersoek.

\section{A model for the criticism of children's literature featuring the environment}

Wildlife and the natural environment have very often provided the backdrop and have frequently been the focus of attention in South African children's literature. Traditional oral literature in the indigenous languages is rich in this subject matter; as for written literature, the very first children's poem set in South Africa was a protest by the English writer, Rev. Isaac Taylor (1820:78), at the hunting of ostriches. The interest continues unabated. Englishlanguage authors' attitudes towards nature, and their didactic motives in writing about it, have varied. Much of what they have produced - which presumably was acceptable to the public at the time of publication - is repugnant to the contemporary reader.

Studies in ecological literary criticism and environmental history contextualise this writing, suggesting how it can be understood, appreciated and evaluated. In South Africa, literary critics and historians have explored the construction of "nature", hunting, indigenous culture, land ownership and use, nature reserves, national parks and their connection with white nationalism, social justice, concepts of nature conservation, and environmentalism. English-language children's literature, in turn, has a contribution to make to these studies, although literary scholars have largely neglected it.

Defining "ecologically-oriented criticism", Dan Wylie (2001:83) explains that it

... pursues some satisfactory triangulation of the dynamics of: a) observed social, scientific, and environmental contexts; b) a stylistically or aesthetically based criticism of literary works being produced within those contexts; and c) an ethical standpoint which is neither narrowly sectarian and masking of the complexities of the works themselves, nor disengaged from the real-world effects of the works. 
This model is an appropriate guide to criticism of children's literature featuring the environment. The first of Wylie's points covers the work of historians, necessary for placing children's books in their social context. I have found the studies by Jane Carruthers (1993; 1995) and David Bunn (1996) particularly useful for this purpose.

Secondly, children's literature should be subjected to stylistic and aesthetic criticism, like any other literature. Compared with other countries which produce substantial numbers of children's books in English, South Africa has a very small corpus of stylistic criticism on the subject. Since it requires detailed analysis of texts, I am unable to pursue this in the present article.

Thirdly, criticism of children's literature must include taking an ethical standpoint, since the literature is intended for young, unformed readers, and it has, at least in part, a didactic intention.

Critics of children's literature clarify both aesthetic and ethical standards for the benefit of, first, those who produce the books (authors, illustrators, translators, editors and publishers); secondly, those such as salespeople, parents, teachers and librarians who make them available to children and mediate between children and the texts; and thirdly, the young readers themselves.

\section{Hunting}

Historical studies such as those of MacKenzie (1988), and environmental criticism, for example by Gray (1979), have given considerable attention to hunting and the construction of "nature" that it reflects.

Nineteenth-century children's books set in South Africa, both fiction and non-fiction, epitomise colonial and imperialistic assumptions of power and the right to strip colonised lands of their natural assets. They made much of wild animals, which they showed being hunted for sport, trophies, scientific collections, food, or the commercial value of their tusks, hides and feathers (Jenkins, 2002a). Initially, writers such as T. Mayne Reid portrayed hunters killing predators for trophies or the thrill of the chase and the danger involved; but as the twentieth century advanced, writers such as Percy FitzPatrick and Victor Pohl put more emphasis on other motives. For example, they suggested that visiting hunters killed predators in order to protect local residents, or because the predators were depleting the supply of antelope that the hunters wanted to shoot for the pot. 
Writers admired, feared or despised animals, and projected their conception of human society onto them by giving them human qualities. Predators, for example, were stamped as evil and ruthless. This kind of anthropomorphism continued well into the twentieth century in the books of Victor Pohl such as Bushveld adventures (1940) (Jenkins, 1993:63-67), and in fact is still common today in non-fictional children's books on dinosaurs, which sort them into goodies and baddies (Scanlon \& Buckingham, 2003).

Hunting featured progressively less in children's books in the twentieth century, except in historical novels and a few anachronistic books such as Pohl's. Hunting for commercial gain now featured in the form of whale hunting and the slaughter of seal cubs to protect fishing resources. Laurens van der Post's The hunter and the whale (1967) used whaling allegorically and as a test of character for boys, but never questioned its ethics. From that there was a leap of only 21 years to When whales go free by Dianne Hofmeyr and Song of the surf by Dale Kenmuir, both published in 1988, which feature angst-ridden boys who reject their fathers' role in these traditional harvestings. This rejection is central to their strained relations with their fathers, while the readers are swayed to disapprove of the slaughter because the boys are portrayed sympathetically.

Nowadays, although hunting for sport and trophies continues to be a popular pastime for the white hunting fraternity and wealthy overseas hunters, publicly it is hardly mentioned - the media carry only hostile coverage of scandals such as "canned" lion hunting and it does not feature in children's books. No author or publisher for children would want to appear so politically incorrect as to endorse it.

\section{Farms}

Almost all the nineteenth-century adventure stories involving hunting were written by non-resident Britishers such as Ballantyne, Kingston, Marryat and Mayne Reid. South African children's writers emerged at the end of the century, by which time the heyday of imperialist writing was over. By the early twentieth century, the country had been domesticated, divided up into farms, which became the popular setting for English-language children's books. Although most English-speaking whites lived in towns, their children's stories suggest that they hankered after rural life, since writers made the Karoo and the Bushveld their symbolic heartland, with occasional diversions to the coast. It was on farms that fictional little children grew up and older ones spent their holidays, either 
living out their placid lives of racial privilege or engaging in improbable adventures with crooks. Four strands of interaction with the environment emerged: vestiges of fear of wild Africa; domestication and miniaturisation; nature lessons; and farming (good farming methods and how farming was affected by drought and veld fires).

Many postcolonial critics (for example, Brantlinger 1988) have pointed out how whites feared Africa as a place of darkness. This is easy to demonstrate from nineteenth-century boys' adventure stories, but no-one has remarked on the traces of the Englishspeakers' half-fearful fascination with the mysterious that lingered in mid-twentieth-century literature such as the immensely popular books by Lawrence Green, T.V. Bulpin, Lyall Watson and Credo Mutwa.

Literary historians such as Egoff and Saltman (1990) and Niall (1984) have remarked on how Canadian and Australian children's literature has depicted nature as something apart from human society: in Canada, wildest nature was a nurturer of the few humans who ventured there, while in Australia, untamed nature was regarded as terrifyingly dangerous. South Africa, on the other hand, has contributed a large corpus of children's literature in which farms and nature reserves form liminal zones in which, or by means of which, humans interact with nature.

Three dramatic stories of the second half of the twentieth century played on the liminality of farms as the borderline between civilisation and the last traces of the old, untamed wilderness, which is symbolised by wild animals which irrupt into farms. "The claws of the cat" (1959) is a short story by Stuart Cloete about a young boy who defends his family's sheep against a lynx. The story became an accepted part of the canon of reading for high school students, as can be seen from its inclusion in two school anthologies (De Villiers, 1979; Loubser, 1969). In Jamie, a young adult novel by Jack Bennett (1963), a young boy shoots a rogue buffalo which has invaded his family's farm and killed his father. A deadly presence (1982) by Hjalmar Thesen features a leopard that terrorises farms. Heale (1985:60) lists this as a young adult novel in his authoritative bibliography.

The buffalo and the lynx provide boys with desperate tests of character and initiation into manhood, of a degree almost never encountered in urban life; while the black leopard evokes atavistic fears of blackness, and raises questions about the purpose of conservation when it is promoted by the privileged classes once the 
balance between humans and nature has to be artificially maintained.

In contrast with stories of danger for young adults, a major genre from the early 1900s until the 1950s consisted of cosy fantasy stories for young children in which animals, birds and insects became little people, modelled on the overseas stories of Uncle Remus, Beatrix Potter, Kenneth Grahame and their like (Jenkins, 1998; 2002b). Writers favoured small creatures such as birds and mice, even when writing of animals in the Kruger National Park. The anthropomorphised creatures acted out fairy-tale fantasies or social comedy (like that of Toad of Toad Hall) about farming society. Although the writers were South African, the stories show that they were clearly English-speaking town dwellers, not all that conversant with their country's fauna and flora. Furthermore, they made factual mistakes and got Afrikaans and African-language names wrong.

Non-fiction that taught lessons about natural history also often enlisted fantasy for its purposes. Dr. H.S. Skaife (1928) reduced a boy to the size of the insects, birds and fish with which he had salutary encounters. Dr. James MacKay (1915) described an extraordinary variety of creatures, many very small, such as "psychids and caddis worms", each of which speaks in comic verse. Cecil Shirley (1943) told stories in which he anthropomorphised the "wee people" of the veld such as porcupines, weasels and butterflies. Like MacKay, he supported the stories with notes. Straightforward nonfiction for children, other than school text books, on animals, birds and flowers was also published (e.g. Fitzsimons, 1924; Norman, 1928; and Bolus, 1919, respectively).

Until the 1960s the methods of modern, scientific agriculture were of widespread interest in white society: they featured in school syllabuses and Boy Scout tests, and a youth organisation, the Land Service Movement, was devoted to them. Stories and poems dwelt on the ravages of droughts and veld fires, and farm stories often incidentally carried lessons in soil conservation and sound farming methods. A full-length story by George Klerck (At the foot of the koppie, 1929) is filled with tedious socratic dialogue between a scientific expert and a pair of ignorant, obedient children who make good listeners as he expounds on an enormous range of agricultural topics.

Contrary to her contemporaries, Fay Goldie wrote a story (Friends of the bushveld, 1954), about a quixotic white family who turn their farm into a nature reserve, but as a consequence cannot make a 
living out of it: "In the eyes of their neighbours the le Rouxs were not only mad, but dangerous" (Goldie, 1954:17). Goldie was constrained to make them fail, since no reader would have thought it possible for them to succeed. (They are saved from ruin by the discovery of gold treasure in a cave.)

\section{Nature reserves: from preservation to conservation}

As the last suitable land for farming was allocated to whites in the early twentieth century, and the prospect of the extinction of wildlife loomed, various campaigns were launched to create nature reserves. Jane Carruthers (1993), historian of South African nature reserves, has shown how they were first mooted by wealthy Englishspeaking whites for the preservation of game for hunting purposes. The central character of Thesen's A deadly presence (1982), a university graduate who holds a generous research grant, is troubled by this history of privilege to which he is heir: he wants to preserve a leopard that is causing havoc among farmers, while conscious that they have a moral right to kill it.

By the 1920s, the motivation for carving out game reserves shifted to conservation of certain mammals (excluding predators), which was extended in the 1960s to the conservation of entire ecological zones. The preservation of animals for hunting shifted into private hands, and in the twenty-first century is big business for game farmers, while conservation has become the prevailing public ethic. Children's literature has followed this chronology.

Memories of an Africa which was often referred to in popular writing as "Eden" were enshrined in Jock of the bushveld by Percy FitzPatrick (1907), which described a time when the territory of the future Kruger Park was still undemarcated wilderness. For many English-speaking whites, this is the central, if not the only, South African children's book. It is ethically acceptable to contemporary readers since the narrator hunted mostly for food, whereas the books of Victor Pohl, describing how as a young man he pointlessly shot creatures, were popular only until the 1970s, and then rapidly forgotten.

After the Kruger National Park had been established in 1926, game reserves became places which could keep alive for whites the ancestral memories of Africa as a place teeming with game. Children's stories set in the Park followed, featuring either animals (usually anthropomorphised in the usual way), or visiting children. 
One of the best is The monkeys' wedding and other stories for children by Sampie de Wet (1939).

\section{Game reserves and nationalism}

In analysing the history of the establishment of South African game reserves, South African scholars have come to the same conclusion as one of the most influential environmental historians, John MacKenzie (1997:226), that "constructions of nature inevitably have a national or racial component".

Carruthers $(1993: 6,8)$ argues that the circumstances leading to the establishment of the Kruger National Park in 1926 included

the nascent rise of Afrikaner nationalism, the consolidation of a Voortrekker mythology and the search for a unified white South African national identity. The new national park reinvigorated the exclusion of Africans ... [It was] a symbol of cultural unity concentrated around a particular South African asset: wildlife.

When I first researched early South African children's literature (Jenkins, 1998; 2001; 2002b) I was unaware of Carruthers's work; but what I found corroborates her thesis. I was struck by the way that English children's literature between the 1920s and the 1940s promoted white nationalism. The middle-class, urban, Englishspeaking authors were struggling to be "South African": their fantasies, while based on English models, featured South African fauna and flora. If the Afrikaans children in Klerck's At the foot of the koppie (1929) should learn their lessons about farming, remarks the author, "they gave promise of being worthy descendants of those hardy people who saw the dawn of a white race in their new southern country" (Klerck, 1929:7). Their teacher regards their father as "a true patriot" (Klerck, 1929:91) because he is a wise farmer.

World War II saw the culmination of the conversion of Englishspeakers from British expatriates into South Africans that began in 1910. Wartime books such as the immensely popular Cock-Olly stories of May Henderson (1941-44) and We're telling you by C.S. Stokes (1943), which were set in the Kruger National Park, carried overt messages in their texts and peritexts exhorting children to be proud of being, like the animal characters, "true South Africans" (Preface by Isie Smuts, in Henderson 1941: n.p.). 


\section{The perpetuation of outmoded social relations and values}

Game reserves developed another significant function in the 1920s and 1930s. Eco-philosophy is inextricably linked to eco-politics. David Bunn (1996:39) points out, "The idea of compensatory enclaved and conserved natural domains played a key role in the discourse of modernity". He argues that reserves were artificial spaces where white people could go to escape temporarily from urban life and ignore the system of labour reserves and migratory labour on which the economy was based.

In private reserves such as Mala Mala, which belonged to the Natal sugar magnate William Alfred Campbell, the owners maintained the notion of parks as spaces reserved for the privileged few, though no longer hunting preserves. Bunn describes how blacks were restored to the older role of "picturesque labour", and the white men and their senior black staff enjoyed a familiar relationship typical of officers and their sirdars under the British raj.

A paternalist hierarchy of this sort was the unremarked backdrop to most farm stories until the 1960s. The trope of the loyal black retainer who plays a fatherly role towards the young white protagonist goes right back to the earliest boys' adventure stories set in Africa in the nineteenth century, such as Hunting the lions by R.M. Ballantyne (1873) and Hendricks the hunter by W.H.G. Kingston (1884).

While most South African children's books until the 1960s simply reflected the prejudices of their time, it has always been possible to find one or two authors who have taken a principled opposite stand. David goes to Zululand by K. Marshall (1935) typically features a Zulu man, Fagazi Boutelezi, who serves as mentor to the white boy David; but the book condemns the way white hunters treat him. "You, white child, have a full understanding, and at once feel at peace with a black man when you speak to him," Boutelezi tells David, as a preface to asking David not to shame him by paying any attention when he has to play the obsequious servant to the hunters (Marshall, 1935:157).

Laurens van der Post's The hunter and the whale (1967) parallels Marshall's novel in this regard, and is a fictional illustration of Bunn's account of Mala Mala. Van der Post makes much of a 14-year-old white boy's bond with the Zulus and his ability to speak their language. Like David, he respectfully addresses them by their own 
names, despising the custom of whites who give them European names. A wealthy Natal businessman objects to his consorting with "servants" in their quarters. The narrator (the boy once he has grown up) remarks how the magnate dresses his butler in an elaborate uniform while insisting that he should remain barefoot - a typical custom of white employers, he says, which is intended to symbolise their servants' black savagery and enforce their humility in the presence of whites.

Notwithstanding these instances of dissent, the social hierarchy of game reserves has continued to feature in children's books. It was still celebrated in the game ranger stories of Dale Kenmuir as late as 1991. Julia Martin has pointed out that in Tikki's wildlife adventure by David Phiri, published as recently as 1995 and endorsed by the Wildlife Society, the fact that a black child, the son of a game scout, who grows up in a game reserve, does not go to school is unmarked, as though it is a matter of course. This, she argues, "naturalizes the hierarchic, authoritarian (racist?) relations between white warden and black game scout and family" (Martin, 1997:12).

Martin (1997) has identified a cluster of outmoded values in South African children's literature and drama featuring modern nature conservation. She undertook a survey of all the material she could find on the subject that was published or performed between 1986 and 1996; but she missed some important children's books, and, in claiming to have been the first to investigate the subject, also missed a chapter on the subject in my book Children of the sun (Jenkins, 1993).

Citing critiques of eco-philosophy since the 1960s, Martin finds traces of "the role of mainstream Judaeo-Christianity in promoting ways of seeing 'God', 'man' and 'nature' that have been used to justify environmental abuse ... with a simultaneous complicity in the abuses of colonialism, imperialism and phallocentricism". She shows that in some plays and books, these values are perpetuated through simple binarisms.

Martin observes that the old image of game rangers as macho, paramilitary fighters is perpetuated in the stories of Dale Kenmuir, of which Sing of black gold (1991) is an example. Her criticism is near the bone. When Peter Slingsby (1989), a prominent environmentalist and author of children's books such as Leopard boy, observed in Bookchat (Slingsby, 1991:5) that "environmental education is, thankfully, trying to shrug off its macho short-pants-and-green-epaulettesin-the-bush image", Kenmuir, a qualified and experienced nature 
conservator, responded, "I was in the game department in Rhodesia/Zimbabwe for years, and never came across anyone fitting the image Peter Slingsby paints. In fact, these types were scorned in National Parks" (Kenmuir, 1992:15). Nevertheless, Kenmuir's heroes undeniably fit this image.

In contrast, says Martin (1997:17), "in other works, the JudaeoChristian certainties are explicitly questioned". As examples of the latter, she might have given more attention to the works of Pieter Pieterse, such as The misty mountain (1985), written in Afrikaans and translated by him into English.

Martin also argues that in the phallocentric world of traditional nature conservation, nature is stereotyped as feminine. I had already shown in my study (Jenkins, 1993) that many stories about the environment perpetuate this stereotype by making nature-loving children either fey girls or delicate, sensitive (that is, feminine) boys.

The silences in children's books on certain aspects of the history of nature conservation cannot be overlooked. None, for example, mentions the forced removal of black people to make way for nature reserves.

\section{The role of traditional beliefs in modern ecological practices}

English and Afrikaans translations, adaptations and imitations of indigenous folktales were prolifically published in books for children throughout the twentieth century. The retellers, publishers and important personages who wrote prefaces and endorsements gave clear indications in the peritexts of the books as to how they perceived the indigenous people (Jenkins 1993; 2002c). The contents and manner of retelling are ripe for ideological analysis.

African pastoralists and San people are commonly portrayed in these books as natural conservators. Nick Greaves (1988:14) typically introduces When hippo was hairy:

By then, there was only one role left in the great scheme of things, so the Creator and Mantis assigned this place to the Bushman - that of Hunter-Gatherer. The Bushman fulfilled his designated role faithfully, living in close harmony with the animals, birds and the plants upon the earth.

Greaves's collections of tales are in fact an out-and-out modernist enterprise, in which he has perversely subordinated folktales to 
"scientific" data about wildlife (Godwin, 1991:111; Jenkins 1993:1415). His sentimentalising of the San is a typical corollary of his Western, technicist paradigm.

A major concern in contemporary cultural analysis, not only in South Africa (for example, Nuttall \& Coetzee, 1998) but also in Canada, Australia and the USA, is the way whites portray indigenous people. Books, museums and art galleries have portrayed them either as stuck in an ahistorical, "primitive" stasis, or as modern people. Recently some critics (such as Naidu, 2001; Jenkins, 1996; 2002c: 270-272; 2002d) have extended this analysis to children's literature, inquiring to what extent children's books of folktales portray black people as primitive.

In children's books of the colonial era, black characters were stereotyped as primitive savages; traditional indigenous hunting methods were regarded as cruel and unnatural; and poaching by blacks, even if it was for subsistence reasons, was a grave offence. While early conservation protected game for the hunting or recreational viewing of whites, modern environmentalism, on the other hand, is bound up with social justice. As Martin (1997) points out, nature conservators are attempting to identify and acknowledge the African roots of conservation, and they work with displaced and neighbouring African communities. She singles out for praise fiction such as Marguerite Poland's Shadow of the wild hare (1986), Mazizi Kunene's poetry (1982), the African story-telling of Zanendaba Storytellers (1996), and theatre such as that of Nicholas Ellenbogen's Theatre for Africa, which draw on traditional beliefs to expound a philosophy of harmony between humans and nature.

Donnarae MacCann and Yulisa Amadu Maddy, in Apartheid and racism in South African children's literature, 1985-1995 (2001), take the opposite point of view, attacking white authors for presuming to interpret African beliefs. Referring to "the strong element of romanticism that appeals to conservation-minded white readers and to children", they claim, "The black population knows that such works are often a biased white project and that 'ecstatic communion' with the animal world can be a seductive cover-up for white supremacist sermons" (MacCann \& Maddy, 2001:96). They argue that in Witch woman on the Hogsback by Carolyn Parker (1987) and Shadow of the wild hare by Marguerite Poland (1986), "Africans are seen to need Westerners to show them the conservation path" (MacCann \& Maddy, 2001:94): this is "storytelling that posits the white child as the 'Great White Environmentalist' (supplanting the earlier 'Great White Hunter')" (MacCann \& Maddy, 2001:95). 
MacCann and Maddy would have been justified in making this assertion about Goldie's Friends of the bushveld (1954), in which the Zulus and "Thongas", all except "old Sezulu", regard the Le Rouxs as mad for conserving wild animals. Goldie's books are steeped in the patronising racial attitudes of whites in the 1950s. But a close reading of Parker and Poland would show how far white writers had come since then. For Parker and Poland, white children have to learn the true meaning of conservation from black people.

It is difficult for writers to avoid an essentialist position regarding traditional beliefs and lifestyles. Nevertheless, contrary to what MacCann and Maddy say, many whites who retell San and African folktales or create new ones in the same style do so with a sense of humility. A number of picture books and stories for young children use an African setting and characters to convey an overt environmental message in a manner which I cannot accept is racist. A note at the front of one of them, The king who loved birds by Patricia Schonstein Pinnock (1992), which is about an African king, declares, "African Sun Press was established to teach children literacy through ecology. Its books encourage children of all cultures in Africa to care for the earth and each other." I would like to see the response of MacCann and Maddy to this book.

\section{Contemporary children's books}

Since the 1960s, many books for children and young teenagers have made modern concerns in conservation the focus of the plots. The long tradition, in both indigenous folktales and stories by white writers, of anthropomorphising flowers, birds, insects and animals (especially small creatures) has ensured that in contemporary children's books the emphasis is not so much on the "flagship animals" - the "Big Five" - as on the worth of all fauna and flora. Stories of children versus crooks have them battling white, not black, poachers, who poach for money - their target more likely nowadays to be crayfish (Brain, 1997) than elephants - and who steal protected plants (Kühne, 1987; Prettejohn, 1986). Children tackle officialdom that threatens areas of natural importance (Younghusband, 1987) and corporations that dump toxic waste (Briner, 2000). Fantasy stories such as Witch woman on the Hogsback (Parker, 1987) have children fighting forces of evil that threaten the environment.

Many stories, most notably by Pieter Grobbelaar, Cicely van Straten and Marguerite Poland, and picture books such as The king who loved birds (Pinnock, 1992) have been produced in the style of 
indigenous folktales. The insistence, in folktales and their imitations, on harmony in nature and between humans and nature, has led to stories pointing simple lessons about littering (Grobbelaar, 1984), chopping down trees (Brown, 1989) and similar behaviour. Stories featuring the disappearance of the San and the Khoi (McAdorey, 1992; Slingsby, 1996; 2002) not only portray them as natural environmentalists, but draw lessons about genocide.

\section{Wylie's model}

Dan Wylie's model for ecologically-oriented criticism has proved to be helpful in providing an approach to children's books that deal with nature and the environment. First, we can see them in historical and social context: they are the product of, and reflect, trends in attitudes to the environment and in the relationship between South Africans and nature. If by chance a young reader should come across old books today, they should provide that reader with an insight into how far South African society has come since they were written.

Secondly, conceptions of the environment provide a focus for analysis and appreciation of the books. Identifying the environment as a theme has enabled critics to single out and fruitfully compare certain stories, poems, plays and picture books.

Thirdly, in evaluating the ethics of these works we can usefully follow Wylie's endorsement of Wayne Booth's stand in his classic work, The company we keep (Booth, 1988). Booth explores the moral dilemma faced by the reader of literature of a previous era which embodies different values to ours. He rejects the "plea for historical relativism" (Booth, 1988:410), maintaining that readers cannot absolve themselves from taking an ethical stance on the content of old fiction: "I have a positive obligation to an implied author, whose creator is long since dead" (Booth, 1988:165). To argue that contemporary readers must tolerate something because it was "widely accepted" at the time of writing is to argue that if it were widely accepted today they should necessarily assent to it (Booth, 1988:412); to argue that because something was written long ago they need not engage with it is simply to let them off the hook (Booth, 1988:410).

Stories that uncritically portrayed whites as exercising a selfproclaimed, exclusive right to slaughter animals for fun or claim land for reserves, or connived at maintaining the racial and political status quo, deservedly invite our disapproval today. In the same way, we should judge contemporary authors on their treatment of sensitive 
social issues such as the role that black people and their beliefs might play in modern approaches to ecology and conservation.

\section{List of references}

BALLANTYNE, R.M. 1873. Hunting the lions; or, The land of the negro. London: Nisbet.

BENNETT, J. 1963. Jamie. London: Joseph.

BOLUS, H.M.L. 1919. Elementary lessons in systematic botany: Based on familiar species of South African flora. Cape Town: Maskew Miller.

BOOTH, W.C. 1988. The company we keep. Berkeley: University of California.

BRAIN, H. 1997. Who's afraid of spiders? Cape Town: Human \& Rousseau.

BRANTLINGER, P. 1988. Rule of darkness: British literature and imperialism, 1830-1914. Ithaca: Cornell University Press.

BRINER, K.H. 2000. Cassandra's quest. Cape Town: Human \& Rousseau.

BROWN, V.J. 1989. The boy and the tree. Cape Town: Human \& Rousseau.

BUNN, D. 1996. Comparative barbarism: game reserves, sugar plantations, and the modernization of South African landscape. (In Dorian-Smith, K., Gunner, L. \& Nuttall, S., eds. Texts, theory, space: Land, literature and history in South Africa and Australia. London: Routledge. p. 37-52.)

CARRUTHERS, J. 1993. Diverging environments: The influence of national parks on African and white attitudes to nature conservation in South Africa. Paper presented at the Thirty-sixth Annual Meeting of the African Studies Association. Boston, Mass., December 4-7. p.10.

CARRUTHERS, J. 1995. The Kruger National Park: A social and political history. Pietermaritzburg: University of Natal Press.

CLOETE, S. 1959. The claws of the cat. (In The soldiers' peaches and other African stories. London: Collins. p. 154-173. Reprinted in De Villiers, G.E., ed. 1979. Close to the sun: Stories from Southern Africa. Johannesburg: Macmillan. p. 118-132; and Loubser, J.W., ed. 1969. Africana short stories: An anthology from South Africa's past. Alberton: Varia. p. 113126.)

DE VILLIERS, G.E., ed. 1979. Close to the sun: Stories from Southern Africa. Johannesburg: MacMillan.

DE WET, S. 1939. The monkeys' wedding and other stories for children. Pretoria: Van Schaik.

EGOFF, S. \& SALTMAN, J. 1990. The new republic of childhood: A critical guide to Canadian children's literature in English. Toronto: Oxford University Press.

FITZPATRICK, P. 1907. Jock of the bushveld. London: Longmans, Green.

FITZSIMONS, F.W. 1924. The monkeyfolk of South Africa. 2nd edition. London: Longmans.

GODWIN, D. 1991. Discovering the African folk-tale in translation. South African Journal of African Languages, 11(4):109-118.

GOLDIE, F. 1954. Friends of the bushveld. London: Jonathan Cape.

GRAY, S. 1979. Southern African literature: An introduction. Cape Town: David Philip.

GREAVES, N. 1988. When hippo was hairy, and other tales from Africa. Manzini: Bok Books.

GROBBELAAR, P. 1984. The earth must be free. Pretoria: Daan Retief. 
HEALE, J. 1985. Young Africa booklist. Glasgow/London/Cape Town/ Johannesburg: Blackie/Book Promotions.

HENDERSON, M. 1941-1944. The Cock-Olly book: Tales of veld, fun and frolic. Durban: Knox.

HENDERSON, M. 1943a. Looma, teller of tales: More stories of Kruger Park. Durban: Knox.

HENDERSON, M. 1943b. Tortoo the tortoise: Ruler of Kruger Park. Durban: Knox.

HENDERSON, M. 1944. Mrs Mouse of Kruger Park. Durban: Knox.

HOFMEYR, D. 1988. When whales go free. Cape Town: Tafelberg.

JENKINS, E.R. 1993. Children of the sun: Selected writers and themes in South African children's literature. Johannesburg: Ravan.

JENKINS, E.R. 1996. Images of the San. (In Machet, M., Ölen, S., Van der Walt, T., eds. Other worlds, other lives: Children's literature experiences. Pretoria: Unisa. p. 270-296.)

JENKINS, E.R. 1998. Talking animals, Kruger National Park, the Libyan Desert, Fairyland and Arabian Nights. (In A sense of space. SAVAL Conference Papers. Johannesburg: University of the Witwatersrand. p. 623-631.)

JENKINS, E.R. 2001. Reading outside the lines: Peritext and authenticity in South African children's books. The Lion and the Unicorn, 25(1):115-127.

JENKINS, E.R. 2002a. South Africa in English-language children's literature, 1814-1912. London: McFarland.

JENKINS, E.R. 2002b. Fairies on the veld. (In Harper, G., ed. Comedy, fantasy and colonialism. London: Continuum. p. 89-103.)

JENKINS, E.R. 2002c. Adult agendas in publishing South African folktales for children. Children's Literature in Education, 33(4):269-284.

JENKINS, E.R. 2002d. With this kind of record, how can we be sure? scrutiny2, 7(2):71-73.

KENMUIR, D. 1988. Song of the surf. Cape Town: Maskew Miller Longman.

KENMUIR, D. 1991. Sing of black gold. Pretoria: De Jager-HAUM.

KENMUIR, D. 1992. Response to "Guest spot". Bookchat, 104:15.

KINGSTON, W.H.G. 1884. Hendricks the hunter; or, The border farm. A tale of Zululand. London: Hodder \& Stoughton.

KLERCK, G. 1929. At the foot of the koppie. Cape Town: Maskew Miller.

KÜHNE, K. 1987. The secret of big toe mountain. Cape Town: Human \& Rousseau.

KUNENE, M. 1982. The ancestors and the sacred mountain. London: Heinemann.

LOUBSER, J.W., ed. 1969. Africana short stories. An anthology from South Africa's past. Alberton: Varia.

MACCANN, D. \& MADDY, Y.A. 2001. Apartheid and racism in South African children's literature, 1985-1995. New York/London: Routledge.

MACKAY, J.G. 1915. Some South African insects. Described in rhyme with nature notes from a southern clime. Durban: Davis.

MACKENZIE, J. 1997. Empire and the ecological apocalypse: the historiography of the imperial environment. (In Griffiths, T. \& Robin, L., eds. Ecology and empire: Environmental history of settler societies. Edinburgh/ Pietermaritzburg: Keele University Press/University of Natal Press. p. 215228.)

MACKENZIE, J. 1988. The empire of nature: Hunting, conservation and British imperialism. Manchester: Manchester University Press. 
MARSHALL, K. 1935. David goes to Zululand. London: Nelson.

MARTIN, J. 1997. Long live the fresh air! Long live! Teaching and truth-telling about the environment in South Africa, 1986-96. scrutiny2, 2(2):10-29.

MCADOREY, U.K. 1992. The old man of the mountain. Manzini: Macmillan Boleswa.

NAIDU, S. 2001. The myth of authenticity: Folktales and nationalism in the "new South Africa". scrutiny2, 6(2):17-26.

NIALL, B. 1984. Australia through the looking glass: Children's fiction 18301980. Melbourne: Melbourne University Press.

NORMAN, D.L. 1928. A bird-book for South African children. Cape Town: Juta.

NUTTALL, S. \& COETZEE, C., eds. 1998. Negotiating the past: The making of modern memory in South Africa. Cape Town: Oxford University Press.

PARKER, C. 1987. Witch woman on the Hogsback. Pretoria: De Jager-HAUM.

PHIRI, D. 1995. Tikki's wildlife adventure. Cape Town: Houston.

PIETERSE, P. 1985. The misty mountain. Pretoria: De Jager-HAUM.

PINNOCK, P.S. 1992. The king who loved birds. Grahamstown: African Sun.

POHL, V. 1940. Bushveld adventures. Fifth edition. Johannesburg: APB.

POLAND, M. 1986. Shadow of the wild hare. Cape Town: David Philip.

PRETTEJOHN, A. 1986. The poacher of hidden valley. Pretoria: Daan Retief.

SCANLON, M. \& BUCKINGHAM, D. 2003. Deconstructing dinosaurs: imagery, fact, and fiction in information books. Bookbird, 41(1):14-20.

SHIRLEY, C.J. 1943. Little veld folk. Cape Town: CNA.

SKAIFE, S.H. 1928. The strange adventures of John Harmer. Parts I, II, III. Cape Town: Maskew Miller.

SLINGSBY, P. 1989. Leopard boy. Cape Town: Tafelberg.

SLINGSBY, P. 1991. Guest spot. Bookchat, 103:5.

SLINGSBY, P. 1996. The joining. Cape Town: Tafelberg.

SLINGSBY, P. 2002. Jedro's bane. Cape Town: Tafelberg.

STOKES, C.S. 1943. We're telling you. Cape Town: Kathbriadon.

TAYLOR, I. 1820. Scenes in Africa. For the amusement and instruction of little tarry-at-home travellers. London: Harris.

THESEN, H. 1982. A deadly presence. Cape Town: David Philip.

VAN DER POST, L. 1967. The hunter and the whale. London: Hogarth.

WYLIE, D. 2001. Elephants and compassion: Ecological criticism and Southern African hunting literature. English in Africa, 28(2):79-100.

YOUNGHUSBAND, P. 1987. Kobie and the mililtary road. Cape Town: Capricorn.

Key concepts:

children's literature; South Africa, English

environment; conservation of

national parks

Kernbegrippe:

kinderlektuur; Suid-Afrika, Engels

nasionale parke

omgewing; bewaring van 
